\title{
Identifikasi Aktivitas Manajemen Perubahan Organisasi pada Implementasi ERP di PT Perkebunan Nusantara XI Menggunakan Model ADKAR
}

\author{
Rizki Nugraha A, Achmad Holil N.A dan Eko Wahyu T.D \\ Jurusan Sistem Informasi, Fakultas Teknologi Informasi, Institut Teknologi Sepuluh Nopember (ITS) \\ Jl. Arief Rahman Hakim, Surabaya 60111 Indonesia \\ e-mail: holil@its-sby.edu
}

\begin{abstract}
Abstrak-Enterprise Resource Planning (ERP) merupakan sistem yang kompleks sehingga angka kegagalan dalam proyek implementasinya sangat tinggi. Manajemen perubahan merupakan salah satu faktornya. PT Perkebunan Nusantara XI (PTPN XI), salah satu perusahaan Badan Umum Milik Negara (BUMN) yang bergerak dibidang agribisnis akan mengimplementasikan ERP sehingga perlu manajemen perubahan yang baik agar implementasi berjalan sukses.

ADKAR merupakan salah satu model manajemen perubahan organisasi. Model ini digunakan sebagai dasar perencanaan strategi manajemen perubahan organisasi di PTPN XI. Manajemen perubahan dapat diinisiasi melalui strategi yang diwujudkan dengan berbagai aktivitas untuk membangun kesadaran (awareness), menumbuhkan keinginan (desire) dan memberikan pengetahuan (knowledge). Seluruh aktivitas ini didapatkan dari hasil analisis dari literatur yang disesuaikan dengan kondisi di PTPN XI melalui observasi, wawancara dan diskusi dengan Kepala Divisi TI PTPN XI.

Hasil dari penelitian ini berupa kumpulan aktivitas manajemen perubahan yang dipetakan berdasarkan pada elemen ADKAR dan diurutkan berdasarkan tingkat keefektifan dari masingmasing elemen ADKAR
\end{abstract}

Kata Kunci-ERP, Manajemen Perubahan Organisasi, Model ADKAR, PTPN XI, Strategi.

\section{PENDAHULUAN}

$\mathrm{P}$ T Perkebunan Nusantara XI (PTPN XI) merupakan salah satu perusahaan Badan Umum Milik Negara (BUMN) yang bergerak dibidang agribisnis perkebunan dengan bisnis utamanya adalah gula. PTPN XI ini memiliki 16 pabrik gula, 4 rumah sakit, 1 poliklinik, 1 pabrik karung plastik dan 1 pabrik penyulingan alkohol dan spiritus[1]-[2].

Sebagai salah satu dari 14 PTPN di Indonesia, PTPN XI ingin mengimplementasikan sistem ERP. ERP merupakan sistem paket yang saling terintegrasi yang mendukung keseluruhan aktivitas-aktivitas bisnis inti dalam perusahaan [3]. Salah satu software ERP yang jumlah penggunanya selalu bertambah adalah SAP [4]. SAP merupakan salah satu piranti lunak dalam sistem ERP yang menyediakan modul-modul untuk memberikan efisiensi bagi perusahaan karena telah mengadopsi best practice perusahaan di seluruh dunia [5].

Menurut Martin et al. [6], ada tiga manfaat penting dengan implementasi ERP, diantaranya: (1) integrasi data yang memudahkan dalam akses data dari suatu unit bisnis ke unit bisnis lain, (2) memberikan kesempatan dalam melakukan rekayasa proses sehingga dapat megurangi biaya proses bisnis dan berorientasi pada proses, (3) memberikan kemampuan dan daya saing global karena dengan mengimplementasikan sistem ERP, perusahaan telah mengimplementasikan proses bisnis kelas dunia.

Pada kenyataannya, banyak proyek implementasi ERP mengalami kegagalan. Bahkan, $70 \%$ merupakan angka "standar" kegagalan dalam proyek implementasi ERP. Sebuah riset oleh The Standish Group menyebutkan hanya 10\% perusahaan berhasil mengimplementasikan ERP, 35\% proyek dibatalkan dan sisanya 55\% mengalami keterlambatan [7].

Banyak faktor yang menyebabkan kegagalan proyek implementasi ERP. Dari beberapa hasil studi menyebutkan faktor yang memegang peran penting dalam kesuksesan implementasi ERP adalah support dari Top Executive. Selain itu, faktor manajemen perubahan juga memegang peran penting [8]. Pada penelitian internal SAP yang dilakukan pada 82.000 implementasi ERP diseluruh dunia menunjukkan bahwa manajemen perubahan menyumbang $40 \%$ kesuksesan implementasi ERP. Abrahamson juga menekankan bahwa manajemen perubahan harus dilakukan dengan cara-cara yang diterima oleh semua elemen di organisasi [9]. Jadi, sebenarnya terdapat kaitan erat antara kedua faktor tersebut. Setelah adanya dukungan dari Top Executif, maka perlu melakukan manajemen perubahan agar proyek berjalan sukses, hal ini pernah diteliti oleh Jack dan Peiper [10]. Bahkan Wahyu Adi, S.T., CPM pakar dari ERP dan chain management dari PT Danone Aqua juga menjelaskan manajemen perubahan yang efektif harus dimulai dari awal proyek dan rencana manajemen perubahan harus diintegrasikan dengam rencana proyek ERP [11].

Manajemen perubahan menurut Wibowo [12] merupakan proses yang sistematis dalam menerapkan pengetahuan, sarana dan sumber daya yang diperlukan untuk mempengaruhi perubahan pada orang yang akan terkena dampak. Salah satu model manajemen perubahan adalah ADKAR yang terdiri atas elemen awareness, desire, knowledge, ability dan reinforcement [13].

Berangkat dari permasalahan tersebut maka terlihat bahwa dalam sebuah implementasi ERP perlu adanya manajemen perubahan organisasi. Bentuk manajemen perubahan organisasi pada implementasi ERP dapat berupa aktivitas-aktivitas yanag dapat menunjang keberhasilan dari implementasi ERP. 


\section{URAIAN PENELITIAN}

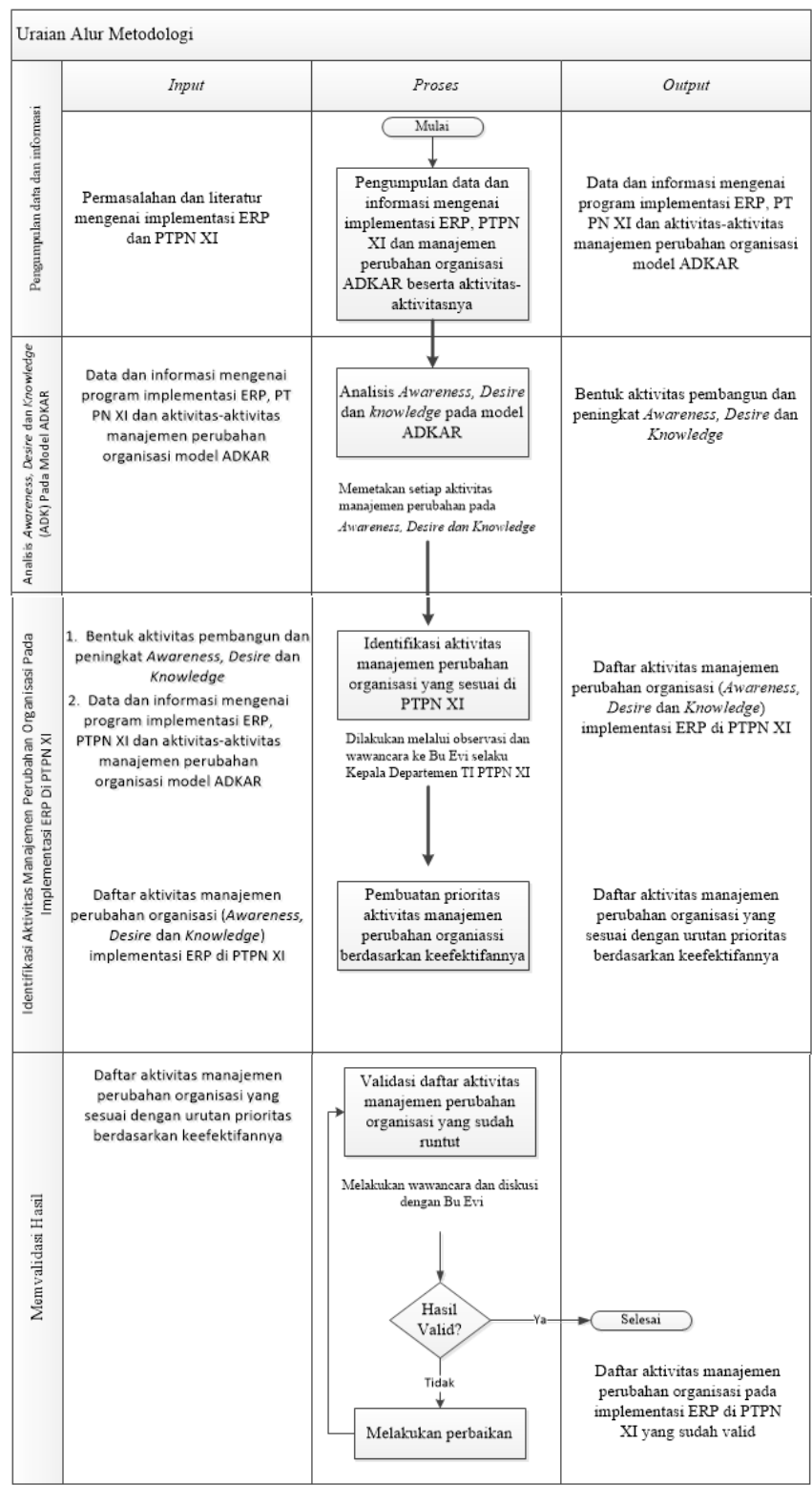

Gambar 1. Metodologi Penelitian

\section{A. Tahap Pengumpulan Data dan Informasi}

Pada proses ini dilakukan pengumpulan data dan informasi dari berbagai literatur. Sehingga input dari proses ini adalah permasalahan dan literatur mengenai implementasi ERP dan organisasi yang dijadikan penelitian yakni PTPN XI. Hasil dari proses ini adalah data dan informasi mengenai implementasi ERP, studi kasus penelitian yakni PTPN XI dan aktivitasaktivitas dalam manajemen perubahan organisasi model ADKAR.

\section{B. Tahap Analisis Awareness, Desire dan Knowledge pada Model ADKAR}

Analisis yang dilakukan berupa pemetaan atas elemen awareness, desire dan knowledge pada model ADKAR dengan tahapan implementasi ERP di PTPN XI.

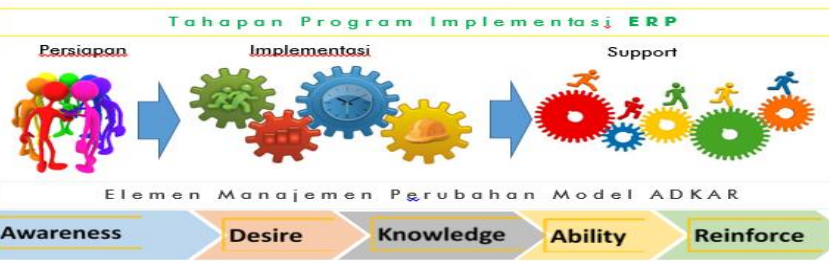

Gambar 2. Pemetaan Tahap Implementasi ERP dengan Model ADKAR

Dari hasil pemetaan tersebut terlihat bahwa tahap persiapan program implementasi ERP terdapat elemen awareness. Dalam model ADKAR, pada tahap awareness tersebut juga akan melibatkan elemen lain yakni desire dan knowledge. Ketiga elemen tersebut saling berkaitan dan bergerak fleksibel, artinya apabila ada elemen yang dirasa kurang, maka dapat kembali ke elemen sebelumnya untuk perbaikan.

\section{Tahap Identifikasi Aktivitas Manajemen Perubahan Organisasi pada Implementasi ERP di PTPN XI}

Setelah mendapatkan bentuk aktivitas membangun awareness, desire dan knowledge yang berdasarkan pada penelitian-penelitian sebelumnya, maka langkah selanjutnya adalah mengidentifikasi aktivitas-aktivitas yang memungkinkan untuk dilakukan di PTPN XI. Kemudian, daftar aktivitas tersebut disesuaikan dengan kondisi kekinian dari PTPN XI yang didapatkan dari hasil pengamatan (observasi) di lingkungan kerja dan wawancara dengan Kepala Divisi TI.

Hasil proses tersebut adalah daftar aktivitas manajemen perubahan organisasi pada implementasi ERP di PTPN XI. Kemudian dari daftar tersebut dibuat sebuah prioritas yang runtut berdasarkan tingkat keefektifannya.

\section{Tahap Memvalidasi Hasil}

Proses validasi dilakukan melalui wawancara dan diskusi dengan kepala Divisi TI di PTPN XI terkait hasil yang diperoleh. Setelah divalidasi, maka hasil akhir dari tahap ini adalah sebuah daftar aktivitas manajemen perubahan organisasi pada implementasi ERP di PTPN XI yang sudah valid.

\section{HASIL DAN DISKUSI}

\section{A. Analisis Elemen Awareness, Desire dan Knowledge}

Berdasarkan hasil literatur studi, hasil wawancara serta teori aktivitas manajemen perubahan organisasi, maka didapatkan strategi manajemen perubahan organisasi yang diwujudkan pada melalui aktivitas-aktivitas berikut:

\section{* Elemen Awareness}

Pada tahap awareness lebih menekankan pada aktivitasaktivitas untuk menjalin komunikasi dan membangun kesadaran kepada para karyawan mengenai hal-hal berikut:

1. Terkait kondisi bisnis

a. Situasi dan kondisi bisnis saat ini, termasuk kebutuhan bisnis untuk berubah, kompetisi dan persaingan bisnis, permasalahan mengenai pelanggan dan keuangan.

b. Kondisi jika tidak berubah, termasuk jika tidak mengimplementasikan ERP.

2. Terkait Perubahan

a. Hubungan perubahan dengan visi perusahaan

b. Ruang lingkup perubahan, termasuk proses, organisasi dan TI 
c. Tujuan perubahan dan waktu perubahan

d. Keselarasan perubahan dengan strategi bisnis

e. Besar perubahan yang dilakukan

f. Yang terkena dampak

g. Dasar mengenai apa yang berubah, bagaimana akan berubah dan kapan berubah termasuk apa yang akan tidak berubah

3. Terkait dampak perubahan kepada karyawan

a. Dampak perubahan terhadap aktivitas karyawan

b. Perspektif "what's in it for me (apa untungnya bagi saya)" dari karyawan

c. Implikasi perubahan terhadap pekerjaan

d. Perilaku dan aktivitas tertentu yang diharapkan dari karyawan

e. Prosedur mendapatkan bantuan dan feedback

f. Ekspetasi bahwa "perubahan akan terjadi dan bukan merupakan pilihan".

4. Terkait pembaharuan status dan laporan kemajuan

a. Schedule proyek secara umum

b. Kapan informasi baru akan tersedia

c. Bagaimana informasi mengenai proyek tersebut akan dibagikan

d. Cerita sukses implementasi

Dari hal-hal tersebut, kemudian diwujudkan dalam beberapa pokok pembahasan yang dilakukan melalui kegiatan atau aktivitas-aktivitas berikut:

a. Pengarahan Mengenai Perubahan di Rapat Direksi

Rapat yang dipimpin oleh direktur utama dan dihadiri oleh seluruh direktur fungsional perusahaan ini biasanya membahas mengenai rencana kerja operasional di tingkat korporasi, pembahasan laporan manajemen, terkait pengelolaan pabrik gula serta hal strategis lain.

Dalam rapat ini, direktur utama dapat mengingatkan adanya implementasi ERP serta memberi pengarahan ke seluruh direktur fungsional mengenai adanya perubahan proses bisnis agar direktur fungsional dapat mempersiapkan proses bisnis baru sekaligus hal-hal lain yang berkaitan dengan perubahan proses bisnis tersebut.

b. Pembahasan Perubahan Individu di Rapat SDM

Implementasi ERP memberikan dampak perubahan dari sisi SDM organisasi yang merupakan tangggung jawab dari divisi SDM. Oleh sebab itu, diperlukan adanya rapat yang dihadiri oleh seluruh kepala divisi di PTPN XI guna mengingatkan kembali bahwa implementasi ERP akan dilakukan dan akan memberikan dampak pada karyawan. Beberapa informasi yang juga perlu disampaikan diantaranya:

- Informasi mengenai perubahan aktivitas karyawan terkait implementasi ERP

- Informasi mengenai perlunya sebuah bantuan ketika karyawan mengalami kesulitan

- Informasi mengenai kapan dan informasi apa saja yang berkaitan mengenai proyek implementasi ERP dan perubahan-perubahan aktivitas dll yang penting untuk dibagikan kepada seluruh karyawan

\section{c. Penyisipan Bahasan ERP di Rapat Divisi}

Rapat ini harus diselenggarakan oleh setiap divisi dan diketuai oleh kepala divisi masing-masing. Dalam rapat ini, kepala divisi dapat mengingatkan kembali adanya implementasi ERP serta menyampaikan informasi hasil rapat SDM. Pada pembahasan kerja operasional fungsional tingkat divisi, kepala divisi dapat menyisipkan bahasan ERP yakni adanya perubahan proses pada fungsi-fungsi tersebut.

\section{d. Melakukan Spamming E-mail Mengenai ERP.}

Apabila sebelumnya Divisi TI melakukan spamming e-mail untuk menginformasikan adanya aplikasi atau update aplikasi. Maka dalam tahap awareness ini dapat digunakan untuk mendistribusikan hasil rapat. Selain itu, perlu dilakukan beberapa perubahan di elemen e-mail, diantaranya mengubah foto profil, menyisipkan header dan footer serta mengganti background e-mail menjadi hal-hal yang berkaitan dengan implementasi ERP.

\section{e. Penyisipan Bahasan ERP di Majalah "Eleven"}

Majalah "Eleven" merupakan majalah PTPN XI yang diterbitkan secara internal. Majalah ini hendaknya diterbitkan kembali secara rutin dan menyisipkan beberapa pokok pembahasan ERP didalamnya, berupa:

- Bagian opini, berisi opini manajemen mengenai implementasi ERP dan perlunya manajemen perubahan untuk mendukung implementasi ERP

- Bagian teknologi, berisi gambaran sistem ERP secara umum

- Bagian berita, berisi mengenai berita persiapan perusahaan dalam implementasi ERP dan berita keberhasilan PTPN lain dalam implementasi ERP

\section{f. Pembuatan X-banner dan Spanduk}

$\mathrm{X}$-banner biasanya digunakan untuk menginformasikan adanya aplikasi baru seperti WBS (wistle blower system) dapat dimanfaatkan untuk memuat strategi perusahaan atau roadmap mengimplementasikan ERP dan countdown ERP mulai digunakan. Sedangkan spanduk yang biasanya digunakan untuk memperingati hari-hari besar, dapat dimanfaatkan untuk mengajak karyawan agar mendukung kesuksesan implementasi ERP.

g. Mengaktifkan dan Menggunakan Kembali Forum atau Group Online

Forum atau group online yang berupa group whatsapp dan group di website perlu diaktifkan kembali karena dapat memudahkan dalam menjalin dan meningkatkan komunikasi. Strategi yang digunakan berupa memperbarui data dan menggunakann group untuk membagikan informasi mengenai inti rapat, hasil rapat dan agenda rapat. Perubahan elemen dalam group yang dilakukan dapat berupa mengubah foto profil group "PTPN XI siap implementasi ERP" dan menambahkan hashtag (\#) "siap ERP, siap perubahan"

\section{h. Mengadakan Sosialisasi Mengenai ERP}

Sosialisasi diberikan langsung oleh direktur kepada seluruh karyawan mengenai beberapa hal, diantaranya:

- Materi perkembangan dan kondisi bisnis

- Materi strategi PTPN XI menghadapi persaingan

- Materi perubahan proses bisnis

- Materi integrasi data dan proses

- Materi tahapan implementasi ERP

- Informasi prosedur mendapat bantuan. 


\section{i. Membuat Slide Presentasi dan Video Mengenai ERP}

Video digunakan untuk memberikan kemudahan dalam menggambarkan proses bisnis ERP, integrasi dan real time data. Pada slide PowerPoint dilakukan penyisipan footer mengenai "PTPN XI akan implementasi ERP".

\section{* Elemen Desire}

Pada tahap desire ini, aktivitas manajemen perubahan organisasi dilakukan untuk menumbuhkan keinginan dan mencegah adanya penolakan para karyawan untuk berubah. Dalam menciptakan desire, diperlukan penciptaan kondisi yang membuat mereka tertarik dan ingin berubah, yakni:

- Kondisi yang lebih personal dan kekeluargaan

- Kondisi yang profesional

Dari kedua kondisi tersebut dapat diwujudkan melalui aktivitasaktivitas dibawah ini:

a. Menyediakan Fasilitas "Mendengarkan Pendapat Karyawan"

Pentingnya menciptakan kondisi yang lebih kekeluargaan untuk menciptakan desire, melalui:

- Menyediakan sesi khusus mendengarkan pendapat di rapat divisi

- Menyediakan alamat $e$-mail untuk menampung pendapat

- Menampung aspirasi melalui forum atau group online.

b. Menunjukkan Manfaat dan Perubahan yang Lebih Baik atas Implementasi ERP Melalui Sosialisasi

Sosialisasi yang diselenggarakan oleh divisi TI ini dilakukan dengan mendatangkan implementator dan direktur PTPN lain yang telah berhasil dan sukses mengimplementasikan ERP. Dalam sosialisasi ini, pembahasan yang disampaikan lebih pada manfaat dan perubahan lebih baik atas implementsi ERP. Selain itu, melalui sosialisasi ini menumbuhkan ekspetasi adanya peningkatan karir karena jika PTPN XI telah mengimplmentasikan ERP, maka PTPN XI telah mengadopsi proses bisnis standar internasional sehingga secara tidak langsung meningkatkan karir karyawan karena dapat bekerja di perusahaan dengan proses bisnis standar internasional

\section{c. Membuat Sebuah Komitmen}

Sebuah komitmen perlu dibuat, ditandatangani dan disaksikan oleh seluruh karyawan untuk mendukung proses implementasi ERP dan perubahan. Komitmen tersebut berisi perjanjian untuk mendukung implementasi ERP dan adanya konsekuensi jika melanggarnya.

\section{d. Melakukan Pendekatan Personal}

Kegiatan one-to-one meeting perlu dilakukan dari seorang kepala divisi dengan staf dalam satu divis jika ada satu atau beberapa staf yang menolak atau tidak mendukung perubahan.dan implementasi ERP. Bentuk pendekatan personal lain diwujudkan melalui penyebutan atau menyapa nama di $e$ mail, undangan sosialisasi, majalan dan saat kegiatan rapat.

\section{* Elemen Knowledge}

Pada tahap knowledge lebih merujuk pada memberikan pengetahuan dan kemampuan kepada para karyawan mengenai:

- Pengetahuan mengenai kondisi dan keadaan dimasa medatang setelah terjadi perubahan, termasuk proses, prinsip dan sistem yang baru
- Pengetahuan mengenai ketrampilan yang dibutuhkan oleh karyawan

Dari kedua pengetahuan tersebut dapat diwujudkan melalui aktivitas-aktivitas, yakni:

a. Mengadakan Pelatihan Komputer Rutin

Adanya implementasi ERP, pelatihan komputer perlu dilakukan secara rutin. Pelatihan komputer yang diadakan oleh Divisi TI ini dikhususkan bagi para calon user ERP baik dari divisi TI maupun dari divisi lain ini untuk lebih memantapkan para calon user ERP dalam menggunakan komputer dan memperbaiki kesalahan-kesalahan kecil dalam komputer dari sisi software dan hardware

\section{b. Mengadakan Program Edukasi ERP}

Program edukasi secara teori memberikan pengetahuan mengenai beberapa hal, yakni:

- Kondisi dimasa mendatang setelah terjadi perubahan, termasuk proses, prinsip dan sistem yang baru

- Pengenalan terhadap proses dan istilah-istilah yang digunakan dalam ERP

- Proses ERP pada masing-masing fungsional

- Fitur-fitur dan penggunaan ERP

- Peran termasuk job description baru

Program edukasi secara praktik dilakukan dengan mempraktikkan menggunakan sistem ERP.

\section{c. Menyediakan Modul dan Bahan Terkait ERP}

Terkait adanya program edukasi ERP secara teori dan praktik, maka juga diperlukan sebuah modul berupa softcopy dan hardcopy yang dibuat oleh divisi TI atau pihak ketiga (konsultan ERP) untuk memudahkan peserta dalam pemahaman.

\section{d. Menyediakan Akses Informasi Terkait ERP}

Perlunya akses informasi mengenai beberapa hal yang didistribusikan melalui e-mail, yakni:

- Informasi mengenai penjadwalan proyek implementasi ERP secara umum

- Informasi mengenai proses implementasi secara umum

- Informasi umum mengenai software yang akan digunakan,

- Informasi mengenai deskripsi pekerjaan bagi calon user ERP nantinya

e. Menyediakan sebuah group atau forum

Group atau forum online pada group whatsapp dan group website pada tahap knowledge dimanfaatkan untuk lebih merujuk pada berbagi pengetahuan dan troubleshooting dengan sesama calon user ERP di seluruh divisi terkait ERP pasca program edukasi ERP.

\section{B. Penyusunan Prioritas Aktivitas Manajemen Perubahan Organisasi}

Daftar aktivitas manajemen perubahan organisasi yang telah diidentifikasi kemudian dilakukan penyusunan prioritas berdasarkan tingkat keefektifan dari masing-masing elemen.

\section{* Elemen Awareness}

Tingkat keefektifan dari aktivitas tahap awareness didasarkan pada teori Information Richness of Communication Channels dan Alistair Cocburn yang didasari oleh beberapa hal, yakni: 
- Komunikan melihat dan mendengar langsung atau tidak langsung

- Ada tidaknya feedback atau question-and-answer

- Bentuk penyampaian verbal atau non-verbal

- Tingkat kepentingan

- Jumlah komunikan atau audiensi

- Jelas tidaknya audiensi yang dituju

Urutan daftar aktivitas ditunjukkan pada tabel 1

Tabel 1.

Daftar Prioritas Aktivitas Manajemen Perubahan Tahap Awareness

Keterangan:

M: aktivitas atau kegiatan sudah ada dan pernah dilakukan di PTPN XI

O: aktivitas atau kegiatan belum ada atau belum pernah dilakukan di PTPN XI.

\begin{tabular}{|c|c|c|c|c|c|}
\hline No & $\begin{array}{l}\text { Daftar } \\
\text { Aktivitas }\end{array}$ & $\begin{array}{l}\text { Feed } \\
\text { back }\end{array}$ & $\begin{array}{l}\text { Bentuk } \\
\text { Penyamp- } \\
\text { aian }\end{array}$ & Audiensi & $\mathrm{M} / \mathrm{O}$ \\
\hline 1 & Rapat direksi & $\mathbf{V}$ & Langsung & $\begin{array}{l}\text { Jajaran } \\
\text { direktur }\end{array}$ & $\mathrm{M}$ \\
\hline 2 & Rapat SDM & $\mathbf{V}$ & Langsung & $\begin{array}{l}\text { Kepala } \\
\text { divisi }\end{array}$ & $\mathrm{O}$ \\
\hline 3 & Rapat Divisi & V & Langsung & Staf divisi & M \\
\hline 4 & $\begin{array}{l}\text { Mengadakan } \\
\text { Sosialisasi } \\
\text { mengenai ERP }\end{array}$ & $\mathbf{V}$ & Langsung & $\begin{array}{l}\text { Seluruh } \\
\text { karyawan }\end{array}$ & M \\
\hline 5 & $\begin{array}{l}\text { Mengaktifkan } \\
\text { dan } \\
\text { menggunakan } \\
\text { kembali forum } \\
\text { atau group } \\
\text { online }\end{array}$ & $\mathbf{V}$ & $\begin{array}{l}\text { Tidak } \\
\text { langsung }\end{array}$ & $\begin{array}{l}\text { Seluruh } \\
\text { karyawan }\end{array}$ & M \\
\hline 6 & $\begin{array}{l}\text { Melakukan } \\
\text { spamming } e \text { - } \\
\text { mail mengenai } \\
\text { ERP }\end{array}$ & V & $\begin{array}{l}\text { Tidak } \\
\text { langsung }\end{array}$ & $\begin{array}{l}\text { Seluruh } \\
\text { karyawan }\end{array}$ & M \\
\hline 7 & $\begin{array}{l}\text { Membuat slide } \\
\text { presentasi dan } \\
\text { video } \\
\text { mengenai ERP }\end{array}$ & & $\begin{array}{l}\text { Tidak } \\
\text { langsung }\end{array}$ & $\begin{array}{l}\text { Seluruh } \\
\text { karyawan }\end{array}$ & $\mathrm{O}$ \\
\hline 8 & $\begin{array}{l}\text { Penyisipan } \\
\text { bahasan ERP } \\
\text { di majalah } \\
\text { "Eleven" }\end{array}$ & & $\begin{array}{l}\text { Tidak } \\
\text { langsung }\end{array}$ & $\begin{array}{l}\text { Seluruh } \\
\text { karyawan }\end{array}$ & M \\
\hline 9 & $\begin{array}{l}\text { Pembuatan X- } \\
\text { banner dan } \\
\text { spanduk }\end{array}$ & & $\begin{array}{l}\text { Tidak } \\
\text { langsung }\end{array}$ & $\begin{array}{l}\text { Tidak } \\
\text { spesifik }\end{array}$ & M \\
\hline
\end{tabular}

\section{- Elemen Desire}

Tingkat keefektifan dari aktivitas tahap desire didasarkan dua hal, yakni hasil survei lembaga survei independen TINY PULSE untuk mencari faktor yang menciptakan keinginan karyawan untuk berubah serta level bentuk penolakan (resistance) atas perubahan oleh R. Maurer. Bentuk daftar prioritas aktivitas ditunjukkan pada tabel 2 .

Tabel 2.

Daftar Prioritas Aktivitas Manajemen Perubahan Tahap Desire Keterangan:

M: aktivitas atau kegiatan sudah ada dan pernah dilakukan di PTPN XI

O: aktivitas atau kegiatan belum ada atau belum pernah dilakukan di PTPN XI

Penolakan level 1: penolakan yang didasari situasi dimana mereka tidak mengerti perubahan apa yang terjadi, hal ini disebabkan karena kurangnya informasi dan kebingungan atas informasi yang beredar.

Penolakan level 2: penolakan karena respon emosional berupa ketakutan akan kehilangan sesuatu seperti pekerjaan, status dll.

Penolakan level 3: penolakan yang didasari kurangnya kepercayaan. Situasi ini juga terjadi karena adanya hal yang belum terselesaikan sehingga memungkinkan terjadi bentrokan ketika terjadinya perubahan ke masa mendatang

\begin{tabular}{|c|c|c|c|c|}
\hline No & Daftar Aktivitas & $\begin{array}{l}\text { Besar } \\
\text { persentase }\end{array}$ & $\begin{array}{l}\text { Level } \\
\text { penolakan }\end{array}$ & $\mathrm{M} / \mathrm{O}$ \\
\hline 1 & $\begin{array}{l}\text { Melakukan } \\
\text { pendekatan personal }\end{array}$ & $\begin{array}{l}20 \% \text { motivasi } \\
\text { teman sebaya }\end{array}$ & 3 & $\mathrm{O}$ \\
\hline 2 & $\begin{array}{l}\text { Menyediakan fasilitas } \\
\text { "mendengarkan } \\
\text { pendapat karyawan" }\end{array}$ & $\begin{array}{l}13 \% \text { merasa } \\
\text { didukung dan } \\
\text { dikenali }\end{array}$ & 2 & M \\
\hline 3 & $\begin{array}{l}\text { Menunjukkan secara } \\
\text { langsung manfaat dan } \\
\text { perubahan yang lebih } \\
\text { baik atas adanya } \\
\text { implementasi ERP } \\
\text { melalui sosialisasi }\end{array}$ & $\begin{array}{l}10 \% \\
\text { memiliki } \\
\text { dampak nyata }\end{array}$ & 1 & M \\
\hline 4 & $\begin{array}{l}\text { Membuat sebuah } \\
\text { komitmen }\end{array}$ & $9 \%$ lain-lain & 1 & $\mathrm{O}$ \\
\hline
\end{tabular}

\section{* Elemen Knowledge}

Tingkat keefektifan dari aktivitas pada tahap knowledge ini berdasarkan pada klasifikasi media pembelajaran dari Edgar Dale yang dikenal sebagai "kerucut pengalaman". Hasil prioritas ditunjukkan pada tabel 3.

Tabel 3.

Keterangan:

Daftar Prioritas Aktivitas Manajemen Perubahan Tahap Desire

M: aktivitas atau kegiatan sudah ada dan pernah dilakukan di PTPN XI O: aktivitas atau kegiatan belum ada atau belum pernah dilakukan di PTPN XI.

\begin{tabular}{|c|c|c|c|}
\hline No & Daftar Aktivitas & $\begin{array}{c}\% \\
\text { Software }\end{array}$ & $\mathrm{M} / \mathrm{O}$ \\
\hline 1 & $\begin{array}{l}\text { Mengadakan program edukasi ERP } \\
\text { (praktik) }\end{array}$ & 90 & $\mathrm{O}$ \\
\hline 2 & Mengadakan pelatihan komputer rutin & 90 & M \\
\hline 3 & Menyediakan sebuah group atau forum & 70 & M \\
\hline 4 & $\begin{array}{l}\text { Mengadakan program edukasi ERP } \\
\text { (teori, termasuk gambar dan video) }\end{array}$ & 30 & $\mathrm{O}$ \\
\hline 5 & $\begin{array}{l}\text { Menyediakan modul dan bahan terkait } \\
\text { ERP }\end{array}$ & 10 & M \\
\hline 6 & $\begin{array}{l}\text { Menyediakan akses informasi terkait } \\
\text { ERP }\end{array}$ & 10 & M \\
\hline
\end{tabular}

\section{Validasi Strategi Manajemen Perubahan Organisasi}

Validasi dilakukan melalui wawancara dan diskusi dengan Bu Evi selaku Kepala Divisi TI PTPN XI pada tanggal 29 Desember 2015 di Ruang Divisi TI PTPN XI. Wawancara dan diskusi tersebut dilakukan dengan memberikan pertanyaan dari daftar strategi yang didapatkan. Kemudian strategi-strategi yang dapat dilakukan dan memungkinkan untuk dilakukan di PTPN XI akan diberi sebuah checklist. Daftar strategi yang dapat atau memungkinkan untuk dilakukan tersebut didapatkan dari hasil jawaban Bu Evi. Dari kegiatan yang telah dilakukan, didapatkan hasil bahwa seluruh aktivitas dapat dilakukan.

\section{KESIMPULAN/RINGKASAN}

Kesimpulan:

Dari penelitian yang dilakukan didapatkan sebuah strategi yang berisi daftar aktivitas manajemen perubahan organisasi yang telah dipetakan berdasarkan elemen ADKAR dan telah diurutkan sesuai prioritasnya serta telah sesuai dengan kondisi PTPN XI adalah sebagai berikut:

\section{Tahap Awareness}

1. Pengarahan mengenai perubahan di rapat direksi 
2. Pembahasan perubahan individu di rapat SDM

3. Penyisipan bahasan ERP di rapat divisi

4. Mengadakan Sosialisasi mengenai ERP

5. Mengaktifkan dan menggunakan kembali forum atau group online

6. Melakukan spamming e-mail mengenai ERP

7. Membuat slide presentasi dan video mengenai ERP

8. Penyisipan bahasan ERP di majalah "Eleven"

9. Pembuatan $\mathrm{x}$-banner dan spanduk

Tahap Desire

1. Melakukan pendekatan personal

2. Menyediakan fasilitas "mendengarkan pendapat karyawan"

3. Menunjukkan secara langsung manfaat dan perubahan yang lebih baik atas adanya implementasi ERP melalui sosialisasi

4. Membuat sebuah komitmen

Tahap Knowledge

1. Mengadakan program edukasi ERP (praktik)

2. Mengadakan pelatihan komputer rutin

3. Menyediakan sebuah group atau forum

4. Mengadakan program edukasi ERP (teori)

5. Menyediakan modul dan bahan terkait ERP

6. Menyediakan akses informasi terkait ERP

Saran:

1. Dalam proses validasi hanya dilakukan oleh satu orang saja, yakni kepala divisi teknologi informasi di PTPN XI. Sedangkan beberapa aktivitas lain dalam proses implementasinya juga membutuhkan persetujuan oleh kepala divisi lain. Oleh sebab itu, perlu dilakukan validasi kepada beberapa kepala divisi lain yang terlibat dalam aktivitas manajemen perubahan organisasi tersebut

2. Menggali lebih dalam informasi mengenai kondisi saat ini (existing) pada studi kasus yakni PTPN XI dengan menambah narasumber untuk wawancara.

\section{DAFTAR PUSTAKA}

[1] "Lembaga Pendidikan Perkebunan." [Online]. Available: http://www.lpp.ac.id/ptpn.php?id=206\&act=view\&ptpn=11. [Accessed: 06-Aug-2015].

[2] "PT Perkebunan Nusantara XI: Profil Singkat Perusahaan." [Online]. Available: http://bumn.go.id/ptpn11/berita/2/Profil.Singkat.Perusahaan. [Accessed: 06-Aug-2015].

[3] Winahyu, "Analisis Faktor-Faktor Penentu Keberhasilan Dalam Implementasi Paket Sistem Enterprise Resource Planning (ERP) untuk Mencapai Keunggulan Bersaing Perusahaan," masters, Program Pasca Sarjana Universitas Diponegoro, 2005.

[4] "Jumlah Perusahaan Pengguna SAP Semakin Bertambah," KOMPAS.com. [Online]. Available: http://regional.kompas.com/read/2009/07/11/10161798/jumlah.perusaha an.pengguna.sap.semakin.bertambah.. [Accessed: 06-Aug-2015].

[5] "SAP Best Practices - SAP Help Portal Page." [Online]. Available: http://help.sap.com/bestpractices. [Accessed: 06-Aug-2015].

[6] M. H. Martin, "An ERP Strategy," Fortune, pp. 95-97, Feb. 1998.

[7] W. M. Ulrich and P. Newcomb, Information Systems Transformation: Architecture-Driven Modernization Case Studies. Morgan Kaufmann, 2010.

[8] Dewi Margareth L Toruan, "Kesuksesan dan Kegagalan Implementasi Enterprise Resource Planning (ERP) dan Contoh Studi Kasus PT Semen Gresik dan Fox Meyer," Institut Pertanian Bogor, Bogor, 2013.

[9] Muhammad Fiitrah, "Faktor-Fakor Yang Mempengaruhi Keberhasilan Implementasi Enterprise Resource Planning," Universitas Indonesia, Depok, 2010.
[10] Todd D. Jick and Maury A. Peiperl, Managing Change: Cases and Concepts. New York, 2002.

[11] "Fakultas-Teknik-Teknik-Industri-Gelar-Kuliah-Tamu-ChangeManagement-for-ERP-Implementation.” [Online]. Available: http://teknik.ub.ac.id/id/berita4482-Teknik-Industri-Gelar-Kuliah-TamuChange-Management-for-ERP-Implementation.htm. [Accessed: 04-Sep2015].

[12] Prof. Dr. Wibowo, S.E., M. Phil, Manajemen Perubahan.

[13] Bandar J Alqahtani, "Improving Safety Behaviour Using ADKAR Model," Am. Soc. Saf. Eng. - Middle East Chapter ASSE-MEC 9th Prof. Dev. Conf. Exhib. PDCE, pp. 1-6, Feb. 2010. 